\title{
Bioethanol production from coconut husk fiber
}

\author{
A produção de bioetanol a partir de fibra de casca de coco
}

\author{
Mirelle Márcio Santos Cabral ${ }^{\mathrm{I}}$ Ana Karla de Souza Abud ${ }^{\mathrm{II}}$ \\ Carlos Eduardo de Farias Silva ${ }^{\mathrm{I}}$ Renata Maria Rosas Garcia Almeida
}

\section{ABSTRACT}

Population growth and the increasing search for healthy foods have led to a major consumption of coconut water and, hence, to an environmental impact caused by the inappropriate disposal of green coconut husks. This lignocellulosic biomass has deserved attention of researchers concerning the seeking of new usages, as, for example, in renewable fuels production technologies. This study examines the potential of green coconut husk fibers as a feedstock for the production of bioethanol. The coconut fibers were pretreated through an alkaline method, hydrolyzed enzymatically and submitted to ethanol fermentation with commercial yeasts of Saccharomyces cerevisiae. Despite the significant loss of cellulose $(4.42 \%$ in relation to the fiber and $17.9 \%$ concerning the original cellulose content), the alkaline pretreatment promoted an efficient solubilization of lignin (80\%), turning the coconut fibers into a feasible raw material for $2 G$ ethanol production studies. Enzymatic hydrolysis converted $87 \%$ of the sugars and the ethanolic fermentation consumed $81 \%$ of the substrate in the hydrolyzate, leading to a sugar to ethanol convertion efficiency of $59.6 \%$. These results points out that green coconut husks are a promising alternative to the production of renewable energy.

Key words: reuse, coconut husk, fermentation, bioethanol.

\section{RESUMO}

O crescimento populacional e a busca por alimentos saudáveis levam a um aumento do consumo da água de coco e, com isso, um impacto ambiental pela maior geração de resíduos, merecendo atenção de pesquisadores para o aproveitamento dessa biomassa, em que uma das tecnologias empregadas é a produção de combustíveis renováveis. Este trabalho avalia a fibra da casca de coco verde pré-tratada com álcali, hidrolisada com enzima e submetida à fermentação etanólica com a levedura comercial Saccharomyces cerevisiae. Apesar da significativa perda em celulose $(4,42 \%$ em relação à biomassa e $17,9 \%$ em relação à celulose presente), o pré-tratamento alcalino apresentou alta solubilização de lignina (80\%), tornando-se viável para estudos da produção de etanol $2 G$. A hidrólise enzimática converteu $87 \%$ dos açúcares e a fermentação etanólica consumiu $81 \%$ do substrato presente no hidrolisado, gerando uma eficiência na conversão de açúcares em etanol de 59,6\%. Tais resultados indicam a casca de coco verde como uma alternativa promissora à produção de energia renovável.

Palavras-chave: aproveitamento, casca de coco, fermentação, bioetanol.

\section{INTRODUCTION}

Biomass is a strategic natural resource for development of new technologies, in which it plays a key role to reduce economic and environmental impacts (BALLAT, 2011). Lignocellulosic residues are among the most important types of biomass, and represent the most abundant sources of carbohydrates worldwide. This lignocellulosic biomass does not compete with the food industry and is particularly attractive for production of bioethanol (SAHA et al., 2013). The main constituents of lignocellulosic biomass are cellulose $\left(\mathrm{C}_{6} \mathrm{H}_{10} \mathrm{O}_{5}\right)_{x}$, hemicellulose $\left(\mathrm{C}_{5} \mathrm{H}_{8} \mathrm{O}_{4}\right)_{\mathrm{m}}$ and lignin $\left(\mathrm{C}_{9} \mathrm{H}_{10} \mathrm{O}_{3}\left(\mathrm{OCH}_{3}\right)_{0.9-1.7}\right)$, which represent $90 \%$ of the biomass dry mass, while ashes and extractives correspond to 10\% (BALAT, 2011). The structural complexity of lignocellulosic biomass, generally defined as recalcitrance, hampers microbial and enzymatic treatments (PU et al., 2013), thereby becoming a critical factor for the use of lignocellulosic residues in the production of biofuels.

\footnotetext{
'Universidade Federal de Alagoas (UFAL), Maceió, AL, Brasil.

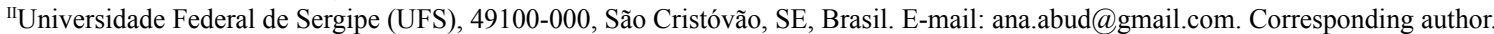
Received 09.22.15 Approved 04.25.16 Returned by the author 07.18.16 CR-2015-1331.R2
} 
Pretreatment of biomass for conversion to $2 \mathrm{G}$ ethanol (second generation ethanol) has shown to be challenging because it must eliminate lignin, reduce crystallinity of cellulose, and dissolve hemicellulose, turning the biomass into a feedstock more susceptible to biological and chemical hydrolysis (SARKAR et al., 2012). Thus, in order to be considered effective, pretreatment methods have to yield large amounts of fermentable sugars, avoiding waste of biomass, degradation of carbohydrates, and formation of inhibitors of hydrolysis and fermentation, being economically viable (SILVA et al., 2015). Currently, pretreatment methods of biomass are classified into biological, physical, chemical or physicochemical methods.

Alkaline pretreatment methods, especially those using sodium $(\mathrm{NaOH})$ and calcium $\left(\mathrm{Ca}(\mathrm{OH})_{2}\right)$ hydroxides in mild conditions, are efficient in removing lignin and side chains of xylans, thus increasing considerably the efficiency of enzymatic saccharification (PARK et al., 2010). $\mathrm{NaOH}$ has been employed in the pretreatment of various types of lignocellulosic biomass, straws of wheat and rice for instance, in which a high efficiency of lignin removal and hemicellulose dissolution by cleavage of ester linkages were achieved, with consequent increase of biomass porosity (KANG et al. 2012).

Brazil is the fourth largest producer of coconuts worldwide, with a production of about 2.8 million tons in an area of 257,000 hectares. The production of green coconut accounts for $15 \%$ of the total coconut production (SENHORAS, 2004; MARTINS \& JESUS JR, 2014). Adoption of healthy dietary habits by the Brazilian society has increased the consumption of coconut water (100-350 million liters/year), leading the coconut husks, which represent $80-85 \%$ of the total weight of the fruit, to become an environmental problem throughout the country.

Coconut husks are frequently disposed in open dumps, slopes and landfills. In addition to contributing to propagate illnesses, degradation of landscapes, and create stink, the coconut husk has become an environmental problem due to forming methane gas, one of the main greenhouse gases, when exposed to anaerobic conditions (BRITO et al., 2004). The coconut husk is difficult to degrade under natural conditions, taking over 8 years to decompose completely into the environment (CARRIJO et al., 2002).

Several alternatives have been proposed to add value to the coconut husk, and avoid or reduce the impact of this lignocellulosic biomass to the environment. Some of these alternatives included the use of coconut husk in agriculture (CARRIJO et al., 2002), automobile industry (COSTA \& GEBARA, 2001) and civil construction (PEREIRA et al., 2013), in the production of briquettes (PIMENTA et al., 2015), enzymes and sound insulators (SENHORAS, 2004), and as a sorbent for heavy metals (OKAFOR et al., 2012). This paper examines the potential of coconut husk fiber in the production of bioethanol after alkaline pretreatment and enzymatic hydrolysis.

\section{MATERIALS AND METHODS}

Green coconut husks were supplied by vendors of coconut water situated at Universidade Federal de Alagoas, Maceió, Brazil. The husk were cut to smaller sizes, sanitized with $100 \mathrm{ppm}$ sodium hypochlorite solution for $15 \mathrm{~min}$ and dried at $50^{\circ} \mathrm{C}$ until constant weight. Subsequently, the coconut husk pieces were crushed on an electric forage and in a blender. The fibers were separated from the powder by sieving.

Alkaline pretreatment was carried out by adding $5 \mathrm{~g}$ of coconut fiber to $100 \mathrm{~mL}$ of $5 \% \mathrm{NaOH}$ solution in an Erlenmeyer flask with capacity of $500 \mathrm{~mL}$. Mixture was then autoclaved at $121^{\circ} \mathrm{C}$ and $1 \mathrm{~atm}$ for $40 \mathrm{~min}$. Afterwards, the reacted mixture was filtered to separate the liquid phase from the solid fraction. Content of sugars in the liquid was determined according to the methodology proposed by MILLER (1959), which consisted in measuring the total reducing sugars (TRS) after hydrolysis with $1.5 \mathrm{M} \mathrm{H}_{2} \mathrm{SO}_{4}$ solution and neutralization with $2 \mathrm{~N}$ $\mathrm{NaOH}$. The solid fraction was washed with distilled water at room temperature until $\mathrm{pH}$ becomes neutral, and dried in an oven at $50^{\circ} \mathrm{C}$ until constant weight. Yield of the alkaline pretreatment was calculated as the ratio between the initial dry mass of fiber $\left(\mathrm{m}_{\text {inicial }}\right)$ and the final dry mass of solid fraction. Chemical composition of the coconut fibers was determined before and after the alkaline pretreatment following the methodology earlier used for the sugarcane bagasse (GOUVEIA et al., 2009).

The enzymatic hydrolysis was performed by adding $1 \mathrm{~g}$ of solid fraction of the coconut fibers obtained in the alkaline pretreatment to $100 \mathrm{~mL}$ of a solution composed of $60 \mathrm{~mL}$ of citrate buffer $(50 \mathrm{mM}$, $\mathrm{pH} 4.8), 38 \mathrm{~mL}$ of distilled water and $2 \mathrm{~mL}$ of the commercial enzyme Accellerase 1500. Hydrolysis reaction was conducted in an orbital shaker incubator at $50^{\circ} \mathrm{C}$ and $150 \mathrm{rpm}$ for $72 \mathrm{~h}$. Separation of the liquid phase from the solid fraction was done by filtration. The liquid phase was characterized in terms of TRS content 
and further submitted to alcoholic fermentation. Solid fraction was discarded. Enzymatic conversion was expressed as the percentage of monosaccharides formed in relation to the concentration of solids in the hydrolysis. Enzymatic conversion and the alkaline pretreatment yield were used to determine the overall percentage yield, which represents the amount of sugars formed in the hydrolysis process in relation to the initial amount of in nature coconut fibers.

The inoculum used in the fermentation process was grown on a YPD medium $\left(10 \mathrm{~g} \mathrm{~L}^{-1}\right.$ yeast extract; $20 \mathrm{~g} \mathrm{~L}^{-1}$ bacteriological peptone, $20 \mathrm{gL}^{-1}$ glucose) for $18 \mathrm{~h}$ at $\mathrm{pH} 5.0$ and $30{ }^{\circ} \mathrm{C}$ using $1 \%$ of dry instant yeast on an orbital incubator shaker running at 100rpm. The fermentation was conducted in $250 \mathrm{~mL}$ Erlenmeyer flasks containing $45 \mathrm{~mL}$ of hydrolyzate and $5 \mathrm{~mL}$ of a nutritional supplement $\left(1 \mathrm{~g} \mathrm{~L}^{-1}\right.$ ammonium sulfate and $1 \mathrm{~g} \mathrm{~L}^{-1}$ potassium phosphate), previously sterilized at $121^{\circ} \mathrm{C}$ for $15 \mathrm{~min}$. The end of the fermentation process was determined by the consumption of sugars and concentration of cells. The cell growth $(\mathrm{X})$ was obtained by measurements of optical density at $\lambda=$ $600 \mathrm{~nm}$ and correlation with a calibration curve (dry weight vs. absorbance). Secondary metabolites were analyzed by high-performance liquid chromatography (HPLC) with a refractive index detector (RID-10A), using an Aminex HPX-87H column $(300 \times 7.8 \mathrm{~mm}$, Bio-Rad), $0.005 \mathrm{M} \mathrm{H}_{2} \mathrm{SO}_{4}$ solution as a mobile phase, flux of $0.6 \mathrm{~L} \mathrm{~min} \mathrm{~m}^{-1}$ and oven temperature of $45^{\circ} \mathrm{C}$. Calibration curve was built by correlating solutions of known concentrations with their respective areas in the chromatograms (GOUVEIA et al., 2009).
The fermentation process was evaluated from calculations of substrate to cell conversion $\left(\mathrm{Y}_{\mathrm{X} / \mathrm{S}}, \mathrm{g} \mathrm{g}^{-1}\right)$, cell to ethanol conversion $\left(\mathrm{Y}_{\mathrm{E} / \mathrm{X}} \mathrm{g}\right.$ $\left.\mathrm{g}^{-1}\right)$, substrate to ethanol conversion $\left(\mathrm{Y}_{\mathrm{E} / \mathrm{S}}, \mathrm{g} \mathrm{g}^{-1}\right)$, maximum specific growth rate $\left(\mu_{\max }\right)$, correctness of linear fit of the $\ln \left(\mathrm{X} / \mathrm{X}_{0}\right)$ vs. time curves, productivity of cells $\left(\mathrm{P}_{\mathrm{X}}, \mathrm{g} \mathrm{L}^{-1} \mathrm{~h}^{-1}\right)$ and ethanol $\left(\mathrm{P}_{\mathrm{E}}\right.$, $\mathrm{g} \mathrm{L}^{-1} \mathrm{~h}^{-1}$ ), ratio between the maximum change of cellular concentration $\left(\mathrm{g} \mathrm{L}^{-1}\right)$ and fermentation time (h). Efficiency of sugar to ethanol conversion ( $\eta, \%)$ was determined as the ratio between $\mathrm{Y}_{\mathrm{E} / \mathrm{S}}\left(\mathrm{g} \mathrm{g}^{-1}\right)$ and the theoretical value $\left(0.511 \mathrm{~g} \mathrm{~g}^{-1}\right)$ of this parameter (HAHN-HÄGERDAL et al., 1994).

\section{RESULTS AND DISCUSSION}

Characterization of the coconut fiber before and after the alkaline pre-treatment with $\mathrm{NaOH}$ is presented in table 1. Results are in good agreement with those reported by CARRIJO et al. (2002) for different cultivars of coconut. The lignin content was observed to be high $(40.10 \%)$, which explains the high durability and strength of the untreated coconut fibers. Untreated coconut fibers also presented high cellulose content $(24.70 \%)$, which is an important feature for the production of $2 \mathrm{G}$ ethanol. This content was similar, for example, to that of the sugarcane bagasse (46.8\%) and sugarcane straw (30.0\%), which are the main raw materials used for producing bioethanol (MORAES et al., 2012).

Alkaline pretreatments are known to remove lignin from biomass, imparting higher

Table 1 - Chemical composition and analysis of the coconut husk fiber after alkali pretreatment, enzymatic hydrolysis and ethanolic fermentation.

\begin{tabular}{|c|c|c|c|c|c|c|c|c|}
\hline \multicolumn{2}{|l|}{ Component } & \multirow{2}{*}{$\frac{\text { Cellulose }(\%)}{24.70}$} & \multicolumn{2}{|c|}{ Hemicellulose $(\%)$} & Lignin (\%) & Ashes (\%) & \multicolumn{2}{|r|}{ Total (\%) } \\
\hline \multirow{2}{*}{ Pretreatment } & efore & & \multicolumn{2}{|c|}{12.26} & 40.10 & 2.56 & \multicolumn{2}{|r|}{82.25} \\
\hline & fter & 55.17 & \multicolumn{2}{|c|}{7.80} & 29.91 & 0.89 & \multicolumn{2}{|r|}{93.77} \\
\hline \multicolumn{2}{|c|}{ CARRIJO et al. (2012) } & 23 to 43 & \multicolumn{2}{|c|}{3 to 12} & 35 to 45 & - & \multicolumn{2}{|r|}{-} \\
\hline \multicolumn{9}{|c|}{ 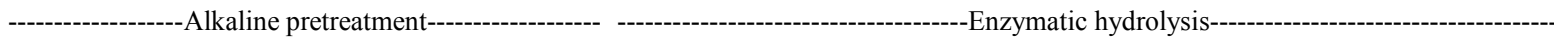 } \\
\hline \multicolumn{2}{|c|}{ TRS $\left(\mathrm{g} 100 \mathrm{~g}^{-1}\right)$} & Mass yield $(\%)$ & \multicolumn{2}{|r|}{$\operatorname{TRS}\left(\mathrm{g} \mathrm{L}^{-1}\right)$} & \multicolumn{2}{|c|}{ Enzymatic conversion $(\%)$} & \multicolumn{2}{|c|}{ Overall yield ( ${\left.\mathrm{g} 100 \mathrm{~g}^{-1}\right)}$} \\
\hline \multicolumn{2}{|c|}{$45.10 \pm 1.56$} & $24.79 \pm 1.70$ & \multicolumn{2}{|r|}{$8.64 \pm 0.46$} & \multicolumn{2}{|c|}{$86.45 \pm 4.67$} & \multicolumn{2}{|c|}{$21.43 \pm 1.16$} \\
\hline \multicolumn{2}{|c|}{$45.86 \pm 4.87$} & $25.69 \pm 2.56$ & \multicolumn{2}{|r|}{$8.84 \pm 0.44$} & \multicolumn{2}{|c|}{$88.40 \pm 4.45$} & \multicolumn{2}{|c|}{$22.71 \pm 1.14$} \\
\hline \multicolumn{2}{|c|}{$43.21 \pm 4.17$} & $26.48 \pm 2.24$ & \multicolumn{2}{|r|}{$8.64 \pm 0.34$} & \multicolumn{2}{|c|}{$86.45 \pm 3.42$} & \multicolumn{2}{|c|}{$22.89 \pm 0.90$} \\
\hline$\Delta \mathrm{X}\left(\mathrm{g} \mathrm{L}^{-1}\right)$ & $\Delta \mathrm{S}\left(\mathrm{g} \mathrm{L}^{-1}\right)$ & $\Delta \mathrm{E}\left(\mathrm{g} \mathrm{L}^{-1}\right)$ & $Y_{X / S}\left(\mathrm{~g} \mathrm{~g}^{-1}\right)$ & $Y_{E / S}\left(g^{-1}\right)$ & $\mu_{\max }\left(h^{-1}\right)$ & $P_{X}\left(g^{-1} h^{-1}\right)$ & $E\left(g^{-1} h^{-1}\right)$ & $\eta(\%)$ \\
\hline 0.13 & 13.20 & 4.02 & 0.010 & 0.305 & 0.038 & 0.015 & 0.447 & 59.60 \\
\hline
\end{tabular}

$\Delta \mathrm{X}=$ variation in growth of biomass; $\Delta \mathrm{S}=$ variation in substrate consumption, measured in TRS (total reducing sugars); $\Delta \mathrm{E}=\mathrm{variation}$ in the production of ethanol; $\mathrm{Y}_{\mathrm{X} / \mathrm{S}}=$ substrate to cell conversion; $\mathrm{Y}_{\mathrm{E} / \mathrm{S}}=$ cell to ethanol conversion; $\mu \mathrm{max}=$ maximum specific growth rate; $\mathrm{P}_{\mathrm{X}}=$ productivity of cells; $\mathrm{P}_{\mathrm{E}}=$ productivity of ethanol; $\eta=$ efficiency of sugar to ethanol conversion (theoretical relative to Gay-Lussac equation where $1 \mathrm{~g}$ glucose yields $0.511 \mathrm{~g}$ of ethanol). 
reactivity to the fibers. Lignin content of the coconut fibers decreased from 40.10 to $29.91 \%$ after alkaline pretreatment with $\mathrm{NaOH}$. Accordingly, the cellulose content increased from 24.70 to $55.17 \%$ and the hemicellulose content reduced from 12.26 to $7.80 \%$. NASCIMENTO et al. (2011) reported that a delignification treatment using $7 \% \mathrm{NaOH}$ for 30 minutes diminished the lignin content of sugarcane bagasse to $5 \%$, leading to a treated biomass containing $38 \%$ of cellulose.

It can be seen that the alkaline pretreatment resulted in a weight loss of approximately $75 \%$ and led to a liquid phase containing a high TRS content, thus confirming that lignin was efficiently solubilized. The NASCIMENTO et al. (2011) obtained a glucose concentration of $55.5 \mathrm{~g} \mathrm{~L}^{-1}$ after enzymatic saccharification of sugarcane bagasse pretreated in alkaline medium $(4 \% \mathrm{NaOH})$ using a solid loading of $10 \%$. The conversion observed was of $77.10 \%$, which was lower than the conversion percentage obtained in this $(87.10 \%)$, most likely due to the high percentage of solids used in the hydrolysis. The overall yield of hydrolysis, which represented the amount of sugar produced in the enzymatic hydrolysis in relation to the initial amount of in nature coconut fiber, was $22.34 \mathrm{~g}$ of reducing sugar per $100 \mathrm{~g}$ of coconut fiber.

Table 1 also reports the cell growth variation $(\Delta X)$, substrate consumption $(\Delta S)$ and ethanol production $(\Delta \mathrm{E})$ in the fermentation, as well as the values of $Y_{E / S}, Y_{X / S}, \mu_{\max }, P_{E}, P_{E}$ and $\eta$. It can be noticed a low cell growth, but large substrate consumption $(81 \%)$ and production of ethanol with a reasonable growth rate $\left(0.76 \mathrm{day}^{-1}\right)$ characteristic of anaerobic processes, fermentative metabolism and low concentration of sugars. SHARMA et al. (2007) reported a maximum ethanol yield of $42.6 \%$ after $48 \mathrm{~h}$ of fermentation of a biomass composed of banana (Musa sp.) and tangerine peels. PAGANINI et al. (2005) observed an ethanol yield of $44 \%$ for the fermentation of apple pomace. ROCHA et al. (2009) optimized the enzymatic hydrolysis of cashew bagasse previously treated by alkaline and acidic methods and obtained ethanol yields between 0.38 and $0.47 \mathrm{~g}$ ethanol $\mathrm{g}^{-1}$ glucose. These yields are in close agreement with the results reported in the present research $\left(0.31 \mathrm{~g}\right.$ ethanol $\left.\mathrm{g}^{-1} \mathrm{ART}\right)$, thus demonstrating an efficient route of enzymatic hydrolysis that showed yield of $30 \%$, or approximately $60 \%$ if only the hydrolysis step is taken into account. This comparison also reveals the potential of the coconut fibers as a feedstock for producing $2 \mathrm{G}$ ethanol.

Figure 1 displays kinetics fermentation and evolution of secondary compounds over the process, which was terminated when the soluble solids ( ${ }^{\circ}$ Brix) became constant. Consumption of substrate decreased over the fermentation process, while the ethanol production was observed to be directly proportional to the cell growth $(\mathrm{X})$.

It can be verified that xylose accounts for $20 \%$ of the TRS content at the beginning of the fermentation, and then this pentose starts to be consumed over time, although it is known that xylose can only be fermented by species of yeast others than Saccharomyces cerevisiae (RODRUSSAMEE et al., 2011). Consumption of xylose may be explained by the degradation of this pentose during the fermentation process or due to its internalization by endocytosis in the Saccharomyces cerevisiae yeasts, which, although did not metabolize pentoses, are capable of absorbing them internally (SUBTIL \& BOLES, 2012). Xylitol content was low and remained constant in relation to those of other compounds.

Glycerol concentration increased gradually up to $2.13 \mathrm{~g} \mathrm{~L}^{-1}$, while the acetic acid concentration was constant at approximately $0.40 \mathrm{~g} \mathrm{~L}^{-1}$. PALMQVIST \& HAHN-HÄGERDAHL (2000) cited that the presence of organic acids at concentrations larger than $6 \mathrm{~g} \mathrm{~L}^{-1}$ decreases the production of biomass and ethanol, although the concentration figure 1 displays the kinetics fermentation and evolution of secondary over HHG process of acetic acid, which is formed from degradation of hemicellulose, and was not considered as a limiting factor to fermentation. Glycerol is a secondary metabolite of alcoholic fermentation, being important for the growth of the Saccharomyces genus, which synthesized the compound from pentoses and hexoses. Synthesis of glycerol is dependent on the cultivation conditions (growth, formation of acids, stress, etc.) (GUTIERREZ, 1991).

The viability of producing $2 \mathrm{G}$ ethanol from biomass needs to be evaluated also with respect to the losses of sugars in the pretreatment step. As aforementioned, there was a loss of hemicellulose and cellulose of the coconut fiber of $84 \%$ and $44 \%$, respectively, in the pretreated broth, which accounts, before the pretreatment, for approximately $21.22 \%$ of the original fiber, and $54.70 \%$ of total sugars present in fiber $(10.91 \%$ cellulose $+10.31 \%$ hemicellulose $)$. In order to contribute to the viability of the process, alternative usages for these sugars must be created, such as the consortium with yeasts that ferment pentose and/or detoxification of the broth due to the likely presence of inhibitors of fermentation.

It was obtained an overall yield of $0.078 \mathrm{~g}$ ethanol $\mathrm{g}^{-1}$ untreated coconut fiber. Based on the 

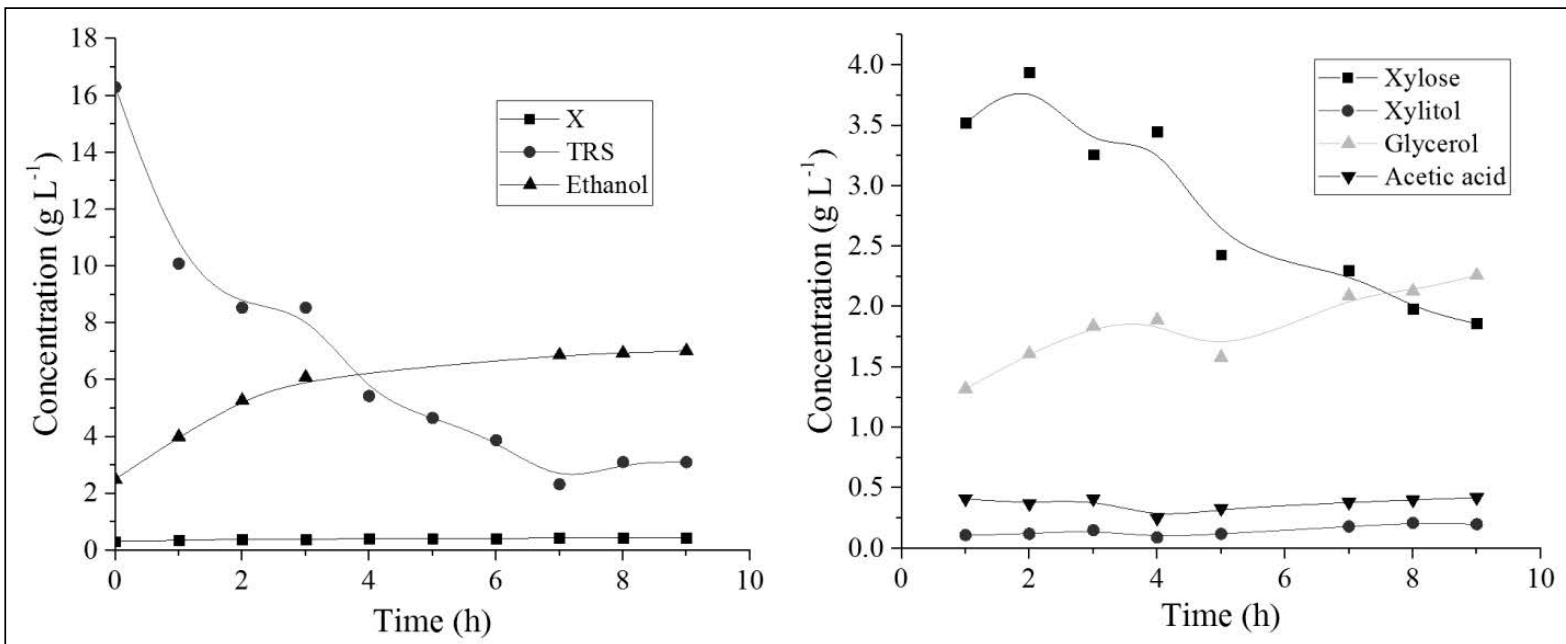

Figure 1 - Kinetic profile of coconut husk fermentation and secondary compounds formed $(\mathrm{X}=$ biomass; TRS $=$ total reducing sugars).

total sugar content of the coconut fiber $(36.96 \%)$ and sugar content eliminated in the pretreatment $(21.22 \%)$, only $15.74 \%$ of sugars remained in the pretreated fiber. According to the theoretical conversion of Gay-Lussac (1 $\mathrm{g}$ of glucose provides $0.511 \mathrm{~g}$ of ethanol) the theoretical maximum yield is $0.0804 \mathrm{~g}$ ethanol $\mathrm{g}^{-1}$ untreated fiber. Thus, $97 \%$ of the theoretical yield was reached in this study for the sugars present in pretreated coconut fiber, but not taking into account the sugars lost in the alkaline pretreatment or the pentose fermented in the enzymatic hydrolysis. This represents an excellent result and indicates an efficient hydrolytic methodology.

\section{CONCLUSION}

An alkaline pretreatment was successfully applied on green coconut fibers to obtain a viable feedstock for production of $2 \mathrm{G}$ ethanol. Despite the significant loss of cellulose and solubilization of lignin (80\%), an efficient enzymatic hydrolysis, with $87 \%$ of conversion and overall yield of $22.34 \mathrm{~g}$ ART $100 \mathrm{~g}^{-1}$ of coconut fiber, and efficient fermentation of coconut fiber sugars were accomplished. The consumption of sugars in the hydrolyzate was of approximately $81 \%$, and the ethanol conversion efficiency was $59.6 \%$ and $48.3 \%$ for the fermentation and the overall process, respectively, considering the Gay-Lussac relationship. Fermentation yields between 43 and $49 \%$ are considered to be appropriate, and indicative of a good fermentation process, which strongly points out the viability of using the green coconut husk as a feedstock for the production of $2 \mathrm{G}$ ethanol.

\section{ACKNOWLEDGEMENTS}

The authors are grateful to Conselho Nacional de Desenvolvimento Científico e Tecnológico (CNPq) for the financial support.

\section{REFERENCES}

BALAT, M. Production of bioethanol from lignocellulosic materials via the biochemical pathway: a review. Energy Conversion and Mangement, v.52, n.2, p.858-875, 2011. Available from: <http://www.sciencedirect.com/science/article/ pii/S0196890410003791>. Accessed: Jan. 20, 2015. doi: 10.1016/j.enconman.2010.08.013.

BRITO, E.O. et al. Properties of particleboard made with Cocus nucifera residues and Pinus elliottii particles. Floresta e Ambiente, v.11, n.2, p.01-06, 2004. Available from: <http://www.floram.org/files/v11n2/v11n2a1.pdf $>$. Accessed: Jan. 14, 2014.

CARRIJO, O.A. et al. Fiber of green coconut shell as an agricultural substrate. Horticultura Brasileira, v.20, n.4, p.533-535, 2002. Available from: <http://www.scielo.br/pdf/hb/ v20n4/14486.pdf>. Accessed: Feb. 15, 2015.

COSTA, J.E.; GEBARA, J.J. The production of coconut chain in Sergipe. In: GERARDI, L. H.O. (Org.). Teoria, técnica, espaços e atividades: temas de geografia contemporânea. Rio Claro: UNESP, 2001. p.177-198.

GOUVEIA, E.R. et al. Validation of methodology for the chemical characterization of sugar cane bagasse. Química Nova, v.32, n.6, p.1500-1503, 2009. Available from: <http://www.scielo.br/pdf/ qn/v32n6/26.pdf $>$. Accessed: Feb. 20, 2015.

GUTIERREZ, L.E. Glycerol production of strains of Saccharomyces during alcoholic fermentation. Anais da Escola Superior de Agricultura Luiz de Queiroz, v.48, p.55-69, 1991. Available from: <http://www.scielo.br/scielo.php?script=sci_ar ttext\&pid=S0071-12761991000100005 $>$. Accessed: May 20, 2014. doi: 10.1590/S0071-12761991000100005.

Ciência Rural, v.46, n.10, out, 2016. 
HAHN-HÄGERDAL, B. et al. Biochemistry and physiology of xylose fermentation by yeasts. Enzyme and Microbial Technology, v.16, p.933-943, 1994. Available from: <http://www.sciencedirect.com/science/article/ pii/0141022994900027>. Accessed: May 20, 2014. doi: 10.1016/0141-0229(94)90002-7.

KANG, K.E. et al. Pretreatment of rapeseed straw by sodium hydroxide. Bioprocess and Biosystems Engineering, v.35, p.705-713, 2012. Available from: <http://link.springer.com/ article/10.1007/s00449-011-0650-8\#/page-1>. Accessed: May 20, 2014.doi: 10.1007/s00449-011-0650-8.

MARTINS, C.R.; JESUS JR, L.A. Production and marketing of coconut in Brazil front of the international trade: 2014 prospect. Aracaju: Embrapa Tabuleiros Costeiros, 2013. 51p. (Documentos/Embrapa Tabuleiros Costeiros, ISSN 1517$1329 ; 184)$.

MILLER, G.L. Use of dinitrosalicilic acid reagent for determination of reducing sugar. Analytical Chemistry, v.31, n.3, p.426-428, 1959.

MORAES, M.S.A. et al. Analysis of products from pyrolysis of Brazilian sugar cane straw. Fuel Processing Technology, v.93, p.35-43, 2012. Available from: <http://www. sciencedirect.com/science/article/pii/S0378382012000975>. Accessed: May 20, 2015. doi: 10.1016/j.fuproc.2012.03.004.

NASCIMENTO, V.M. et al. Optimization of alkaline (NaOH) pretreatment of sugarcane bagasse for production of second generation bioethanol. In: Symposim on Biotechnology for Fuel and Chemicals, 33., 2011, Seattle, USA, 2011, p.1-6.

OKAFOR, P.C. et al. Adsorption capacity of coconut (Cocos nucifera L.) shell for lead, copper, cadmium and arsenic from aqueous solutions. International Journal of Electrochemistry Science, v.7, p.12354-12369, 2012. Available from: <http://www.electrochemsci.org/papers/ vol7/71212354.pdf $>$. Accessed: May 20, 2015.

PAGANINI, C. et al. Utilization of apple pomace for ethanol production and food fiber obtainment. Ciência e Agrotecnologia, v.29, n.6, p.1231-1238, 2005. Available from: <http://www.scielo.br/scielo.php?script=sci_arttext\& pid $=$ S1413-70542005000600018 $>$. Accessed: May 15, 2014. doi:10.1590/S1413-70542005000600018.

PALMQVIST, E.; HAHN-HÄGERDAL, B. Fermentation of lignocellulosic hydrolysates I: inhibition and detoxification. Bioresource Tecnhnology, v.74, p.17-24, 2000. Available from: $\quad<\mathrm{http}: / / \mathrm{www}$. sciencedirect.com/science/article/pii/ S0960852499001601. Accessed: May 15, 2014. doi: 10.1016/ S0960-8524(99)00160-1.

PARK, I. et al. Cellulose ethanol production from waste newsprint by simultaneous saccharification and fermentation using Saccharomyces cerevisiae KNU5377. Process Biochemistry, v.45, p.487-492, 2010

PEREIRA, C.L. et al. Use of highly reactive rice husk ash in the production of cement matrix reinforced with green coconut fiber. Industrial Crops and Products, v.49, p.88-96, 2013. Available from: <http://www.sciencedirect.com/science/ article/pii/S0926669013002112>. Accessed: Oct. 15, 2015. doi: $10.1016 /$ j.indcrop.2013.04.038.
PIMENTA, A.S. et al. Charcoal briquettes produced with recycled coconut puth. Ciência Florestal, v.25, n.1, p.137144, 2015. Available from: <http://periodicos.ufsm.br/ cienciaflorestal/article/view/17471>. Accessed: Oct. 20, 2015. doi: $10.5902 / 1980509817471$.

PU, Y. et al. Assessing the molecular structure basis for biomass recalcitrance during dilute acid and hydrothermal pretreatments. Biotechnology for Biofuels, v.6, n.15, p.1-13, 2013. Available from: <https://biotechnologyforbiofuels.biomedcentral.com/ articles/10.1186/1754-6834-6-15>. Accesed: Feb. 15, 2015. doi: 10.1186/1754-6834-6-15.

ROCHA, M.V.P. et al. Enzymatic hydrolysis and fermentation of pretreated cashew apple bagasse with alkali and diluted sulfuric acid for bioethanol production. Applied Biochemistry and Biotechnology, v.155, p.407-417, 2009. Available from: <http:// link.springer.com/article/10.1007\%2Fs12010-008-8432-8\#page-1>. Accessed: Feb. 15, 2015. doi: 10.1007/s12010-008-8432-8.

RODRUSSAMEE, N. et al. Growth and ethanol fermentation ability on hexose and pentose sugars and glucose effect under various conditions in thermotolerant yeast Kluyveromyces marxianus. Applied Microbiology and Biotechnology, v.90, n.4, p.1573-1586, 2011. Available from: <http://link.springer.com/ article/10.1007\%2Fs00253-011-3218-2\#page-1>. Accessed: May 15, 2015. doi:10.1007/s00253-011-3218-2.

SAHA, B.C. et al. Hydrothermal pretreatment and enzymatic saccharification of corn stover for efficient ethanol production. Industrial Crops and Products, v.44, p.367-372, 2013. Available from: <http://www.sciencedirect.com/science/article/ pii/S0926669012006140>. Accessed: May 20, 2015. doi: 10.1016/j.indcrop.2012.11.025.

SARKAR, N. et al. Bioethanol production from agricultural wastes: an overview. Renewable Energy, v.1, p.19-27, 2012. Available from: <http://www.sciencedirect.com/science/article/ pii/S096014811100382X>. Accessed: May 20, 2015. doi: 10.1016/j.renene.2011.06.045.

SENHORAS, E.M. Opportunities of agro-industrial chain of green coconut: nothing is lost in green coconut, everything is enjoying. Revista Urutágua, v.5, 2004. Available from: $<$ http:// www.urutagua.uem.br/005/22eco_senhoras.htm $>$. Accessed: Jan. 02, 2014

SHARMA, N. et al. Optimization of fermentation parameters for production of ethanol from kinnow waste and banana peels by simultaneous saccharification and fermentation. Indian Journal of Microbiology, v.7, p.310-316, 2007. Available from: <http:// link.springer.com/article/10.1007\%2Fs12088-007-0057-z\#/page1>. Accessed: May 20, 2015.

SILVA, C.E.F. et al. Citric waste saccharification under different chemical treatments. Acta Scientiarum Technology, v.37, n.4, p.387-395, 2015. Available from: <http://periodicos.uem.br/ ojs/index.php/ActaSciTechnol/article/view/28133/pdf_118>. Accessed: Oct. 15, 2015. doi: 10.4025/actascitechnol.v37i4.28133.

SUBTIL, T.; BOLES, E. Competition between pentoses and glucose during uptake and catabolism in recombinant Saccharomyces cerevisiae. Biotechnology for Biofuels, v.5, n.14, p.1-12, 2012. Available from: <http://biotechnologyforbiofuels.biomedcentral. com/articles/10.1186/1754-6834-5-14>. Accessed: Oct. 20, 2015. doi: 10.1186/1754-6834-5-14. 